\title{
PEMBERDAYAAN PEREMPUAN NELAYAN DALAM PENGEMBANGAN USAHA NUGGET KERANG DESA BLURU KIDUL KECAMATAN SIDOARJO KABUPATEN SIDOARJO
}

\section{Tukiman}

Prodi Ilmu Administrasi Negara, Universitas UPN “Veteran” Jawa Timur, tukiman_upnjatim@yahoo.com

\section{Rosida}

Prodi Teknologi Pangan, Universitas UPN “Veteran” Jawa Timur, rosidaupnjatim@gmail.com

\section{Sonja Andarini}

Prodi Ilmu Administrasi Bisnis, Universitas UPN “Veteran” Jawa Timur, sonjaandarini@rocketmail.com

\begin{abstract}
Abstrak
Pengabdian kepada masyarakat ini adalah pemberdayaan perempuan nelayan dalam pengembangan usaha nugget kerang di Desa Bluru Kidul Kecamatan Sidoarjo Kabupaten Sidoarjo, pelaksanaannya dilakukan dari bulan Maret sampai dengan Juni 2018, metode pengabdian masyarakat ini berupa Pelatihan, Pendampingan dan praktek membuat nugget kerang sesuai dengan resep adonan yang bercita rasa, \& Higienitas produk pangan. Pelatihan, Pendampingan dan praktek manajemen pemasaran Pachaging \& Labeling, monitoring dan pendampingan setelah pelatihan. Konsep ini adalah menciptakan sebuah masyarakat yang mandiri dan kreatif dalam memproyeksikan masa depan mereka, keluarga masyarakat nelayan di Desa Bluru Kidul Kecamatan Sidoarjo Kabupaten Sidoarjo, tidak akan lagi bergantung pada pemerintah setempat dalam pengembangan usaha home industri di desanya, akan tetapi mampu berdiri sendiri dengan potensi yang ada di wilayahnya. Sistim manajemen yang berbasiskan kemandirian dan kreatifitas dalam pengembangan produksi nugget kerang masih jarang ditemukan. Oleh karena itu kedepan desa Bluru Kidul diharapkan menjadi desa percontohan khususnya dalam produksi nugget kerang di Jawa Timur khususnya, dan di Indonesia pada umumnya, terutama bagi wilayah desa-desa pesisir.
\end{abstract}

Kata Kunci: Pemberdayaan, Perempuan Nelayan, Nugget Kerang.

\begin{abstract}
Community service is done by the empowerment of women fishermen by developing shell nugget in Bluru Kidul Village, Sidoarjo Sub-district, Sidoarjo Regency. This activity was conducted from March to June 2018, the methods of community service are training, mentoring, and practice of making shell nugget according to the receipe of dough that flavor and hygiene, marketing management practices of packaging and labeling. It aims to create an independent and creative society in projecting their future, the family of fishermen in Bluru Kidul Village, Sidoarjo Sub-District, Sidoarjo Regency, so that they will no longer rely on local government in developing home industry business in their village. In addition, they will be able to stand on their own with potential in their area. Management system based on independence and creativity in the development of shell nugget production is still rare. Therefore, Bluru Kidul Village is expected to be a pilot village especially in the production of shell nugget in East Java in particular, and in Indonesia in general, especially for coastal villages.
\end{abstract}

Keywords: Empowerment, Women Fishermen, Shell Nugget.

\section{PENDAHULUAN}

Pengembangan usaha nugget dengan bahan dasar kerang di desa Bluru Kidul, merupakan tindak lanjut dari IbM Pemberdayaan Perempuan Nelayan Dalam Pengembangan usaha Bakso Kerang. Hal ini dipandang penting bagi masyarakat di desa Bluru Kidul khususnya keluarga nelayan dalam upaya meningkatkan pendapatan dan kesejahteraan keluarga, karena diprediksi dalam arti akan terus dievaluasi bahwa pembuatan nugget kerang dapat mengalami peningkatan produksi. Disamping perempuan nelayan akan mampu atau berdaya dalam meningkatkan produksi yang besumber dari bahan dasar kerang yang tentunya juga dibarengi dengan peningkatan penghasilan, maka perlu digali potensi lain yang sangat dimungkinkan dapat pula menambah penghasilan keluarga nelayan yakni Pengembangan Usaha Pembuatan Nugget Kerang.

Usaha pembuatan nugget kerang di desa Bluru Kidul, sebenarnya sudah cukup sering dilakukan oleh perempuan nelayan yang tergabung dalam Kelompok Usaha Bersama (KUB), disamping krupuk kerang dan bakso kerang. Namun karena sifatnya spekulasi sehingga belum dapat dikembangkan dengan baik. Oleh karena itu perlu sentuhan dari pihak lain untuk mengembangkan usaha pembuatan nugget kerang tersebut. Kerang sendiri 
merupakan sumber protein hewani yang lengkap mengandung asam amino esensial yang dibutuhkan oleh tubuh kita. Asam amino esensial adalah asam amino yang tidak dapat dibuat didalam tubuh, sehingga mutlak harus berasal dari makanan khususnya kerang.

Mengkaji perempuan tidak dapat dilepaskan dari nilai atau ketentuan yang membedakan identitas sosial laki-laki dan perempuan, serta apa yang harus dilakukan oleh perempuan dan apa yang harus dilakukan oleh lakilaki dalam ekonomi, politik, sosial dan budaya baik dalam kehidupan keluarga, masyarakat dan bangsa (Budiman, 1985; Megawangi, 1997). Pemberdayaan perempuan merupakan proses kesadaran dan pembentukan kapasitas (capacity building) terhadap partisipasi yang lebih besar untuk memiliki kekuasaan dan pengawasan dalam pembuatan keputusan dan transformasi (transformation action) agar perempuan mampu menghasilkan sesuatu yang bermanfaat (Karl,1995 dalam Man Yee Kan, 2002). Memisahkan mata rantai kemiskinan dianggap dapat membebaskan dari ketidakberdayaan dan membebaskan dari kemiskinan, menumbuhkan kekuatan dan memiliki kemandirian. Pemberdayaan perempuan sebagai proses terus menerus untuk meningkatkan kemampuan dan kemandirian perempuan dalam upaya meningkatkan kesejahteraan keluarganya.

Masyarakat pesisir sebagai masyarakat miskin memiliki persoalan yang kompleks, yakni faktor miskin secara ekonomi, terpinggir secara sosial, dan terlupakan secara fungsi dan martabat. Faktor pendidikan dimana tingkat pendidikan masyarakat wilayah pesisir ini sebagian besar masih rendah. Pendidikan menjadi penting karena dengan pemberdayaan masyarakat akan meningkatkan kapasitas pribadi maupun kelompok (Wahyono, 2004). Fungsi kelompok bagi individu adalah memberikan latihan dan dukungan bagi para anggotanya, membantu perkembangan psikologis individu dengan cara memberikan wadah bagi perkembangan intelektualitas maupun emosinya. Sedangkan fungsi kelompok bagi organisasi ialah secara positif kerjasama antara para pekerja diperlukan agar ada semangat tinggi, yang dapat merupakan faktor penting untuk meningkatkan produksi, kesadaran melaksanakan tugas, sehingga akan memperkuat organisasi (Tranggono, 2011). Pendidikan masyarakat merupakan suatu proses dimana upaya pendidikan diwujudkan secara terpadu dengan upaya penduduk setempat untuk meningkatkan kondisi sosial, ekonomi dan budaya yang lebih bermanfaat dan memberdayakan masyarakat. Oleh karena itu diperlukan model pemberdayaan perempuan nelayan melalui pendidikan life skills berbasis ekonomi produktif dengan pemanfaatan potensi lokal dalam upaya meningkatkan kesejahteraan masyarakat pesisir (Mulyono, 2007).
Dari situasi tersebut diatas dapat diuraikan permasalahan-permasalahan yang sedang dihadapi oleh perempuan nelayan dalam pengembangan nugget kerang. Pertama adalah pengetahuan mereka. Pengetahuan mereka tentang pembuatan nugget kerang selama ini hanya didasarkan pada pemahaman mereka sendiri sehingga rasanya kurang mampu bersaing jika dibandingkan dengan jenis nugget kerang yang lain yang sudah membudaya di Indonesia. Permasalahan kedua adalah pemasaran. Selama ini penjualan hasil produksi nugget kerang juga terbatas di lingkungan desa itu sendiri bahkan hanya untuk konsumsi keluarga nelayan itu sendiri. Hal ini tentunya sangat membutuhkan pihak ketiga untuk membantu melakukan promosi penjualan.

\section{METODE}

Penelitian ini merupakan hasil pengabdian kepada masyarakat yang dilakukan di Desa Bluru Kidul Kecamatan Sidoarjo Kabupaten Sidoarjo. Populasinya adalah warga Desa Bluru Kidul Kecamatan Sidoarjo Kabupaten Sidoarjo, dengan sampel penelitian ini meliputi Ketua dan anggota Kelompok Usaha Bersama (KUB) Sumber Rejeki RT.02 RW.07 Desa Bluru Kidul dan Ketua dan anggota Kelompok Usaha Bersama (KUB) Sumber Mawar RT.02 RW.07 Desa Bluru Kidul sebanyak 20 orang ditambah undangan lain yang menyaksikan kegiatan tersebut.

\section{HASIL DAN PEMBAHASAN}

Salah satu masyarakat pesisir di wilayah Kabupaten Sidoarjo adalah masyarakat nelayan di Desa Bluru Kidul. Dalam upaya meningkatkan pendapatan keluarga nelayan di Desa Bluru Kidul antara lain adalah peran serta perempuan nelayan dalam mencari penghasilan tambahan, baik dalam kegiatan mengupas kerang, pembuatan sate kerang, kerang goreng, pembuatan krupuk dan bakso kerang, maupun pembuatan dan pengembangan nugget kerang. Secara history perkampungan di Desa Bluru Kidul sudah dikenal dengan hasil tambak dan sumber kerang yang banyak dihasilkan nelayan, sehingga Kota Sidoarjo disamping sebagai kota udang juga terkenal dengan makanan khas tradisionalnya yaitu lontong kupang dengan sate kerangnya. Namun nugget kerang sebenarnya juga punya potensi untuk dikembangkan; dan karena potensi ini, maka para perempuan nelayan tergerak untuk mengolah hasil tangkapan nelayan antara lain kerang yang diolah dan diproses untuk menjadi "nugget kerang” sebagai sumber tambahan penghasilan keluarga.

Berbagai upaya telah dilakukan, namun belum ada perhatian yang serius dari pihak pemerintah 
setempat maupun pihak investor yang peduli akan hal tersebut, sehingga usaha ini tidak begitu tampak, bahkan cenderung hilang begitu saja. Desa Bluru Kidul terdiri dari 2 pedukuhan, yakni Dukuh Rangkah Lor dan Dukuh Bluru Kidul sendiri. Luas wilayah lebih kurang $260 \mathrm{Ha}$ dengan ketinggian 4-5 m diatas permukaan laut. Batas wilayah Desa Bluru Kidul adalah sebelah utara Desa Kemiri, sebelah selatan Desa Sidoklumpuk, sebelah timur Jalan Lingkar Timur/berbatasan dengan Laut, dan sebelah barat berbatasan dengan Kelurahan Pucang/Kota Sidoarjo; dengan jumlah penduduk 18.618 jiwa. Salah satu potensi yang dimiliki desa Bluru Kidul adalah masyarakat nelayan, yang sudah barang tentu mata pencaharian pokoknya adalah dengan melaut untuk mencari tangkapan kerang dengan jenis kerang yang bermacam-macam; antara lain kerang kukur, kerang balok, kerang batik, kerang macan, kerang sapi, simping, dan kerang darah. Fasilitas umum yang dimiliki di sektor perikanan kerang ini adalah terdapatnya dermaga atau tempat pemberhentian perahu nelayan.

Sebagai wadah nelayan dalam mengumpulkan hasil tangkapan kerang dibentuk kelompok-kelompok usaha bersama antara lain : Kelompok Usaha Bersama (KUB) Sumber Rejeki, KUB Sumber Makmur, dan KUB Sumber Jaya, serta KUB Mawar dan KUB Melati. Kegiatankegiatan yang dilakukan oleh KUB-KUB tersebut adalah : (1). Penangkapan Kerang yang dilakukan di perairan laut selat Madura dengan menggunakan perahu bermesin motor diesel dan dengan alat tangkap seperti garit, garuk, dan alat tradisional lain yaitu ban dan keranjang. Hasil tangkapan nelayan berupa kerang tersebut rata-rata mencapai lebih kurang Rp 1.000.000,- dalam 1 trip melaut dalam bulan-bulan tertentu atau hanya bisa mencapai $\mathrm{Rp}$ 500.000,- s/d Rp 600.000,- di bulan-bulan biasa (tergantung cuaca); (2). Penyediaan Sarana Penangkapan. Hal ini juga merupakan kegiatan yang dilakukan oleh KUB dalam penyediaan sarana seperti alat tangkap berupa perahu, mesin diesel, garuk dan garit, serta ban dan keranjang; disamping kegiatan-kegiatan lain yang berupa sosial kemasyarakatan, seperti kerja bakti pengerukan sedimentasi sungai di Desa Bluru Kidul dan Sedekah Laut/Nyadran yang dilakukan setahun sekali. Tidak kalah pentingnya kegiatan-kegiatan yang dilakukan oleh ibu-ibu atau perempuan nelayan di desa Bluru Kidul dalam mendukung Kelompok Usaha Bersama (KUB) dalam mencari tambahan penghasilan keluarga nelayan yakni dengan membuat krupuk kerang, bakso kerang, nugget kerang, dan lain-lain yang sebenarnya masih banyak potensi lain yang bisa dikembangkan; dalam upaya untuk meningkatkan pendapatan keluarga nelayan. Untuk pembuatan nuget kerang terdapat dua komposisi yaitu komposisi yang asli hanya pakai kerang dan tambahan yang pakai ayam, adapun komposisi tersebut adalah sebagai berikut:

1. Resep Nuget Kerang

a. Kerang 200 gram

b. Bawang putih 3 siung

c. Bawang merah 2 siung

d. Garam 1,5 gram

e. Gula 1,0 gram

f. Merica 1,5 gram

g. Tepung terigu 40 gram

h. Tepung tapioka 30 gram

i. 10.Tepung roti secukupnya

j. 11.Wortel Secukupnya

k. 12.Telur 2 butir

1. 13.Susu 15 gram

m. Untuk resep ke dua pakai daging ayam 100 gram dan kerang 100 gram sedangkan yang lainnya tetap sama.

2. Cara Membuatnya sebagai berikutnya

a. Kerang ditimbang 200 gram

b. Cuci kerang hingga benar-benar bersih

c. Setelah diproses pencucian kerang dihaluskan menggunakan blender atau mixer hingga menjadi seperti bubur

d. Campurkan semua bahan meliputi tepung tapioka 30 gram tepung terigu 40 gram, barang merah 2 siung bawang putih 3 siung, garam 1,5 gram, gula 1,0 gram merica 1,5 gram, susu skim 15 gram, telur 2 butir, tepung roti secukupnya, wortel secukupnya, campurkan bahan-bahan tersebut.

e. Masukkan adonan kedalam loyang dan kukus selama 30 menit

f. Adonan nugget yang telah dikukus didinginkan lalu dipotong sesuai selera

g. Nugget yang telah dipotong dimasukkan kedalam telur dan kemudian digulirkan tepung roti hingga semua adonan nugget tertutup semua

h. Masukkan nugget kedalam freezer

i. Nugget siap untuk digoreng.

Untuk komposisi satu resep tersebut diatas apabila diolah menjadi nuget kerang akan menghasilkan keuntungan mencapai $40 \%$ dengan perbandingan keluaran biaya Rp. 25.000 per resep dengan menghasilkan 48 potong nuget kerang, dan apabila di jual per potong seharga Rp.1.000 akan menghasilkan Rp. 48.000, dan apabila ditambah dengan biaya packaging dan ongkos kerja sebanyak 10.000 keuntugan yang didapat per resep adalah Rp. 13.000.

Pemberdayaan perempuan nelayan dalam pengembangan usaha nugget kerang dilakukan dengan memperhatikan dua poin penting sebagai berikut.

1. Target yang ingin dicapai 
Target dari kegiatan ini adalah pemberdayaan perempuan nelayan dalam pengembangan produksi nugget kerang sebagai tindak lanjut dari pengembangan produksi krupuk dan bakso kerang, yang diharapkan dapat menambah penghasilan bagi keluarga nelayan di desa Bluru Kidul, sehingga akan dapat dicapai pengetahuan yang lebih baik tentang pembuatan nugget kerang termasuk bagaimana strategi komunikasi dalam memasarkan hasil produksi nugget kerang tersebut yang pada akhirnya akan dapat diperoleh kesejahteraan keluarga masyarakat nelayan.

2. Prioritas persoalan dan jalan keluar pemecahan

Penentuan prioritas persoalan berdasarkan kesepakatan tim dan mitra adalah : Pengetahuan tentang pengembangan produksi dalam pembuatan nugget kerang dengan komposisi/resep yang tepat, sehingga dapat menghasilkan cita rasa yang mampu bersaing dengan nugget-nugget yang lain. Oleh karena itu diperlukan konsep/resep bagaimana membuat nugget kerang dengan resep yang tepat.

Manajemen pemasaran. Masalah pemasaran merupakan masalah yang prinsip dalam hubungannya dengan peningkatan produksi. Oleh karena itu kita harus mencari manajemen yang sesuai dan jaringan pemasaran yang cocok agar dapat menumbuh-kembangkan produksi nugget kerang yang dapat menjanjikan untuk dikembangkan, termasuk pachaging dan labeling.

Tak kenal maka tak sayang, itulah salah satu istilah kita dalam memperkenalkan sebuah produk, apalagi ini adalah sebuah "home industri" dengan membandingkan nugget kerang dengan jenis nugget-nugget lain yang sudah membumi, maka nampak jelas bahwa nugget kerang tidak mampu menembus pasar yang lebih luas. Hal ini disebabkan karena terbatasnya jaringan pemasaran yang tidak dibarengi dengan strategi komunikasi pemasaran yang efektif dan benar.

Strategi pada hakekatnya adalah perencanaan (planning) dan manajemen (management) untuk mencapai suatu tujuan. Namun untuk mencapai tujuan tersebut, strategi tidak hanya berfungsi sebagai peta jalan yang menunjukkan arah saja, tetapi harus menunjukkan bagaimana taktik operasionalnya. Strategi komunikasi perlu disusun secara luwes, sehingga taktik operasional komunikasi dapat segera disesuaikan dengan faktor-faktor yang berpengaruh. Untuk mencapai tujuan komunikasi secara efektif, seseorang perlu memahami sifat-sifat komunikasi dan pesan untuk dapat menentukan jenis media yang diperlukan dan teknik komunikasi yang akan ditetapkan (Effendi, 1986: 34). Proses komunikasi dinyatakan berhasil apabila komunikator mampu menyampaikan pesan dan komunikan dapat menerima isi pesan sehingga dapat menimbulkan efek. Oleh karena itu terkait dengan bagaimana memasarkan hasil home industri nugget kerang yang dilakukan oleh perempuan nelayan di desa Bluru Kidul-Sidoarjo, perlu menggunakan strategi komunikasi sehingga mampu menembus pasar sehingga diharapkan mampu bersaing dengan jenis nugget-nugget yang lain yang sudah beredar tersebut.

\section{PENUTUP}

\section{Simpulan}

Pemberdayaan perempuan nelayan dalam pengembangan produksi nugget kerang sebagai tindak lanjut dari pengembangan produksi krupuk dan bakso kerang. Pengembangan produksi ini akan dapat menambah penghasilan bagi keluarga nelayan di desa Bluru Kidul, sehingga akan dapat dicapai pengetahuan yang lebih baik tentang pembuatan nugget kerang termasuk bagaimana strategi komunikasi dalam memasarkan hasil produksi nugget kerang tersebut yang pada akhirnya akan dapat diperoleh kesejahteraan keluarga masyarakat nelayan. Adapun jalan keluar pemecahan masalah untuk meningkatkan perekonomian masyarakat desa dengan mengembangkan produksi nugget kerang dilakukan dengan tiga cara, yakni: pengetahuan tentang pengembangan produksi dalam pembuatan nugget kerang dengan komposisi/resep yang tepat, manajemen pemasaran, dan strategi komunikasi yang efektif dan benar.

\section{Saran}

Pada kegiatan penelitian berbasis pengabdian kepada masyarakat ini perlu melakukan implementasi channel control strategy. Dalam kaitannya dengan hal tersebut maka pendampingan yang dilakukan oleh tim adalah pendampingan terpadu dan berkelanjutan. Pendampingan terpadu yang dimaksud adalah tim akan mendampingi mitra mulai dari kegiatan pelatihan, produksi, sampai dengan pemasaran. Tim akan mendampingi mitra mulai dari perencanaan sampai pada eksekusi kegiatan pengabdian masyarakat termasuk pelatihan pembuatan web terintegrasi dan cyber marketing, bilamana kondisi memungkinkan.

\section{DAFTAR PUSTAKA}

Budiman, 1985. Pembagian Kerja Secara Seksual. PT. Gramedia - Jakarta. Ind.

Effendi, Onong Uchjana, 1986. Dinamika Komunikasi. PT. Remaja Rosdakarya-Bandung

Kotler, Philip dan Gary Armstrong, 1991. Dasar-dasar Pemasaran. Intermedia-Jakarta 
Karl, 1995. Dalam Man Yee Kan, 2002. Gender Arsymetry in the Devision of Labour. Departemen of Sosiology University of Oxford

Megawangi, 1997. Gender Perspektif in Early Childhood Care and Development

in Indonesia. Report Submitted to the Consultative Group on Early Childhood Care and Development, MA, USA

Mulyono, Budi. 2007. Dimensi Sosial Kehidupan Nelayan. PT. Rajawali Press - Jakarta

Tjiptono, Fandy. 2008 (Ed.3). Strategi Pemasaran. Yogyakarta: Andi Offset.

Tranggono, Didiek., 2011. Perilaku dan Kerjasama Kelompok : Komunikasi dan Motivasi Menuju Sukses. (disampaikan pada Pelatihan Pembuatan Krupuk Kerang Terhadap Perempuan Nelayan di Desa Bluru Kidul - Sidoarjo,22 September 2011)

Wahyono, Ari. 2004. Pemberdayaan Masyarakat Nelayan. Media Presindo - Yogjakarta. 